\title{
Teaching and Learning in Survival Mode: Students and Faculty Perceptions of Distance Education during the COVID-19 Lockdown
}

\author{
Maram Meccawy ${ }^{1, *(1)}$, Zilal Meccawy $^{2}$ and Aisha Alsobhi ${ }^{1}(\mathbb{C}$ \\ 1 Department of Information Systems, Faculty of Computing \& Information Technology, \\ King Abdulaziz University, Jeddah 21589, Saudi Arabia; ayAlsobhi@kau.edu.sa \\ 2 English Language Institute, King Abdulaziz University, Jeddah 21589, Saudi Arabia; zmeccawy@kau.edu.sa \\ * Correspondence: mmeccawy@kau.edu.sa
}

Citation: Meccawy, M.; Meccawy, Z.; Alsobhi, A. Teaching and Learning in Survival Mode: Students and Faculty Perceptions of Distance Education during the COVID-19 Lockdown.

Sustainability 2021, 13, 8053.

https://doi.org/10.3390/su13148053

Academic Editors: Eloy

López Meneses,

Mariana-Daniela González-Zamar,

Miguel Martín-Sánchez and

Jorge Cáceres-Muñoz

Received: 17 June 2021

Accepted: 15 July 2021

Published: 19 July 2021

Publisher's Note: MDPI stays neutral with regard to jurisdictional claims in published maps and institutional affiliations.

Copyright: (c) 2021 by the authors. Licensee MDPI, Basel, Switzerland. This article is an open access article distributed under the terms and conditions of the Creative Commons Attribution (CC BY) license (https:// creativecommons.org/licenses/by/ $4.0 /)$.

\begin{abstract}
This study demonstrates how a Saudi university has responded to the COVID-19 lockdown in order to examine the success factors and highlight any challenges. The main purpose was to determine the perceptions of students and faculty towards emergency online distance learning from a teaching and learning perspective; (2) A cross-faculty study was conducted: two different selfadministered questionnaires were developed for students and faculty, respectively. In addition, data was collected from official reports; (3) The results show that students had a more positive perception of e-Learning despite the difficulties that they may have faced, while faculty results leaned slightly towards a negative perception. However, there was not a definite positive or negative perception, depending on the aspect of teaching that was being evaluated. The study also indicated that faculty and students' gender had no significant effect on their perceptions. Overall results showed that the university performed well in accordance with three of the five pillars of online learning quality framework in terms of student satisfaction, access and scalability. On the other, improvements are needed to achieve better results for faculty satisfaction and learning effectiveness; (4) The findings present a number of suggestions for increasing satisfaction to improve the online learning experience post COVID-19.
\end{abstract}

Keywords: COVID-19; distance learning; higher education (HE); e-Learning; student and faculty satisfaction; Saudi Arabia

\section{Introduction}

Distance learning is a form of learning in which learners who are geographically distant have access to the learning process and materials [1]. Online distance learning is a well-established research area with a rich literature. However, the majority of studies focus on designing an online learning experience that would retain the learning values of traditional learning environments and state the measures that need to be taken beforehand, by the learning institution, to ensure its readiness for e-Learning [2-4].

The COVID-19 pandemic forced governments worldwide to implement strict regulations in an effort to contain the highly contagious virus. Saudi Arabia, similar to many other countries, took some precaution measures by suspending any formal or informal face-to-face educational activities. King Abdulaziz University (KAU) was among the higher education institutions that had to deliver their educational services during this sudden crisis. The university has more than 120,000 students enrolled in 185 different majors across 28 colleges, and it offers diplomas, bachelor's, master's and doctoral degrees. KAU was forced to apply online distance teaching in order to survive the pandemic and not compromise the learners' quality of education in the process. This situation resembles what is known as 'survival mode' in digital video games. In such games, the player must continue playing for as long as possible (the remaining period of the semester) without dying in an uninterrupted session (failing to deliver), while the game (the learning environment, government health regulations and resources) presents the players with increasingly 
difficult waves of challenges. This unexpected and unprecedented learning environment, which emerged as a response to the COVID-19 crisis, has been referred to as the emergency remote teaching environment [5].

Prior to the lockdown, KAU was familiar with the concept of distance or online learning. It has previously offered full or partial undergraduate, diploma or continuouseducation online programs. In addition, it has reliable and robust learning management systems (LMS), digital libraries and various educational tools in place; nonetheless, this situation was different. Unlike those aforementioned programs, neither faculty nor students were prepared to shift to this new form just eight weeks into the semester. Hence, the challenge became how to survive this new learning environment, deliver quality education and fair assessments and fully optimize all possible gains from online learning.

This study collected data from official university end-of-semester reports and surveyed both undergraduate students and faculty at KAU at the end of the spring 2020 semester. It gathered their feedback on different aspects of the emergency remote teaching and learning environment. These aspects included teaching and learning and assessment as well as social and technical aspects. A total of 547 responses were received from undergraduate students and 213 responses were received from faculty. This paper only presents the results from the first perspective, teaching and learning. The study is focused on exploring the main factors that affect teaching and learning in higher education during the COVID-19 lockdown. It aims to investigate students and faculty perceptions on this matter. Therefore, the following questions were investigated:

1. To what extent was a higher education institution in Saudi Arabia, namely KAU, ready for a sudden emergency lockdown?

2. What factors, according to students and faculty, may have led to the successful usage of e-Learning systems during this period?

3. What challenges did students and faculty face in this emergency and remote teaching and learning environment?

4. Does gender affect students' and faculty's perceptions towards online teaching and learning?

5. What changes should policy makers and administrators apply in higher education to improve their satisfaction?

The rest of the paper continues as follows: related work is presented in Section 2 followed by the material and methods in Section 3. The results and discussion are presented in Sections 4 and 5, respectively. Moreover, the research implications on the literature and the suggestions presented to policy makers are mentioned in Section 6. Finally, the conclusions are presented in Section 7.

\section{Literature Review}

\subsection{Studies Related to E-Learning Prior to COVID-19}

Viewing e-Learning as an innovative learning experience, many higher education institutions strive to integrate digital technologies into their existing on-campus programs. In addition, many already provide some short courses or full degrees through digital means, typically using an LMS such as Blackboard. However, achieving the same level of quality for both on-campus learners and online learners remains a considerable challenge for higher education institutions. Even without a pandemic, e-Learning can fail for a number of reasons such as technological challenges and low quality of content [6], lack of technical support [7], low university level of readiness [8], lack of faculty IT skills and levels of knowledge [9] and lack of faculty acceptance of the e-system [10].

In order to ensure that distance learning infrastructure, management and resources are successfully implemented, new educational models and frameworks were developed specifically to serve virtual universities. Among those are the Virtual University Reference Model [11], the Virtual University Comprehensive Model [12], the Three Model Layer for Virtual University [13], the Global E-Learning Framework [14], the Sloan Consortium (Sloan-C) Quality Framework [15] and the E-Learning Readiness Model [2]. 
A study that examines the factors influencing faculty satisfaction with online teaching in higher education is presented in [16]. The results confirmed that three factors affect the satisfaction of faculty with online learning. These are student-related, instructor-related and institution-related factors. It highlighted the need to continue to focus on faculty satisfaction because it affects their motivation towards teaching and the likelihood of faculty burnout. Another study, in a Saudi Arabian context similar to our research, was presented by Al-Ghamdi and Samarji [8], who investigated the acceptance of e-Learning systems among higher education faculties. It reported that most of the barriers found in their study were external barriers such as poor internet access, lack of training, lack of technical support, inadequate availability of hardware and software, lack of institutional policy for e-Learning and lack of adequate English language skills. The study concluded that strategic policy makers would need to overcome those barriers.

The satisfaction of students, on the other hand, was measured by a study conducted in a Saudi university with e-Learning systems using TAM3 (Technology Acceptance Model 3) [17]. It found that the most significant factors influencing acceptance of e-Learning among local university students were 'playfulness, self-efficacy, anxiety and perceived usefulness'. An additional study that researches students' satisfaction has been conducted by [18]; it used the UTAUT (The unified theory of acceptance and use of technology) model to measure students' continuous use of the university's e-Learning systems. The findings revealed that performance expectancy and effort expectancy determine whether the university intends to continue the use of e-Learning systems. A third study by [19] was conducted to assess students' perceptions of e-Learning as a mode of teaching and concluded that, while there is a growing positive perception of e-Learning, the level of acceptance of it remains low. Therefore, many improvements need to be made to better integrate e-Learning into Saudi universities.

\subsection{Studies Related to E-Learning Post-COVID-19}

All the aforementioned models, frameworks and research studies were concerned with virtual universities during normal times. In such times, universities had the ability to set their own deadlines to roll out their virtual programs, taking into consideration their resources and capabilities. In the current pandemic, learning institutions had to become virtual overnight. Many have adapted by utilizing their resources as much as they could. The research presented by [20] looked into the response of higher education to the COVID-19 pandemic across 20 countries. The analysis showed diverse responses to a complex challenge. It concluded that some universities were more prepared while others had more issues to overcome.

In Pakistan, a study about students' perceptions of e-Learning during the COVID19 pandemic at a private medical school found that over $77 \%$ of students had negative perceptions. It thus recommended that administrations and faculty take measures to improve e-Learning during lockdown [21]. These findings resonate with similar findings in another study in Pakistan [22]; it examined the attitudes of students, which showed that online learning cannot produce desired results in underdeveloped countries due to technical and financial issues.

One study explored both challenges and factors that influenced the usage of e-Learning systems during the pandemic in six universities in Jordan and Saudi Arabia [23]. It focused on assessing the level of acceptance of the e-Learning systems among students. The findings illustrated that there were technological factors, e-Learning system quality factors, cultural aspects, self-efficacy factors and trust factors that influenced the levels of student acceptance. In addition, a study that aimed to measure the impact of COVID-19 closures on postgraduate students in Saudi Arabia is presented by [24]. This study concluded that the main issues faced by students are technical issues and the added pressure on students to deliver their assignments in a short period of time with limited access to their instructors and supervisors. 
A further study [25] during COVID-19 comes from another developing country, Ghana, and presented the critical factors that affect online learning, such as prior knowledge of e-learning, ICT tools, internet access, online platforms and study materials. It then suggests a number of strategies to apply post-COVID-19 to promote e-Learning. Another study from Ghana [26] investigated learning in higher education during the pandemic. The results showed that overall students had positive response to online learning. However, they had also a negative response because of the lack of formal training, lack of constant access to internet connectivity and financial issues.

The work presented in [27] described the situation in Romania during lockdown, and it involved both school and university students. The results showed that most students have accepted online learning despite finding it less attractive than traditional learning.

A more recent evaluation of online learning in higher education during lockdown took place in a medical school in Malaysia [28]. It found that despite facing some barriers, students had a suitable online learning self-regulation level. Moreover, in the neighboring country of Indonesia, another study was conducted to investigate students perception in higher education during emergency lockdown [29]. The study concluded that students agreed that online learning was the right solution during lockdown, however the lack of proper planning resulted in the absence of easiness, involvement and effectiveness of online learning. The two major complaints were the learning process being dominated by assignments and the high cost of internet connection.

In Bahrain, a neighbouring Arab country to Saudi Arabia, which is also a member of the Gulf Cooperation Council (GCC) and has similar social and traditional norms, a study relating to higher education performance during COVID-19 has been conducted. It focused on student-faculty interaction and investigated the lack of visual interaction in virtual classes and its effect on the learning experience during the pandemic [30]. This study showed that although students were given the option to use video cameras, the majority opted not to. The reasons given included self-consciousness and the lack of private space at home to attend online classes. It concludes that this absence might have affected their learning experience and on allowing them to build a sense of community. This is aligned with a previous (pre-pandemic lockdown) study, which argued that "A disadvantage of the learning environment is often the loss of visual and audible cues which normally are observable from the students" [31]. Moreover, a recent study in 2020 that involved a hybrid virtual classroom, also indicated that "a good quality of audio and video is a crucial factor of successful remote learning" [32]. In our study, the use of video was not an option, as social norms resulted in neither students nor faculty turning on their web cameras. Instead, they used voice and chat for communication in virtual classes. Another recent study from the same region investigated how higher education institutes in GCC countries coped with COVID-19 [33]. It concluded that they have managed to implement online distance learning effectively due to their readiness for digital transformation.

Since the COVID-19 pandemic is still ongoing and online distance learning is still the only available alternative for many universities and higher education institutions worldwide, continuous empirical studies of learning during the pandemic are necessary. These studies are essential to improve the virtual university experience and remove any barriers to learning online. This study aims to evaluate the remote digital learning experience within our local university, looking at the process from two perspectives: those of students as well as their instructors. Other post-COVID-19 studies presented in this literature have lacked this aspect, since many studies focused on either the perceptions of students or those of academic staff, with the majority focusing on the former. Moreover, our research presents a study where virtual learning took place in an LMS but without the use of video cameras due to cultural and social aspects. This has left both faculty and students relaying on other available tools for communication; predominately voice. The situation might be similar in other countries in the region and hence it would give insights and provide useful recommendations to overcome such limitation. 


\section{Materials and Methods}

The spring semester at KAU started on 19 January 2020 and ended on 14 May. The closures of schools and universities were announced on 8 March, and KAU transformed into a virtual university from 9 March onward. Teaching took place in virtual classes online, mainly using the university's LMS, namely Blackboard and Blackboard Ultra; the latter is a lighter version of the original blackboard. Due to social norms and cultural restrictions, webcams were hardly used by the staff or the students.

This study was planned after the closures started, and data was collected from April until the end of the spring semester in 2020. A descriptive cross-faculty study was conducted at KAU's main campus to explore the levels of student and faculty satisfaction. Undergraduate students of all levels, as well as academic staff, participated in the study. According to the Online Learning Consortium Quality Framework [34], previously known as the Sloan-C Quality framework [15], faculty satisfaction is achieved when the institution supports faculty with robust technical infrastructure, training and ongoing technical and administrative assistance. On the other hand, student satisfaction 'reflects the effectiveness of all aspects of the educational experience'; a student who completes the course would express satisfaction with course content, delivery and fairness, professor and peer interaction and support services.

The research methodology framework that was applied in this study was performed in presented in Figure 1.

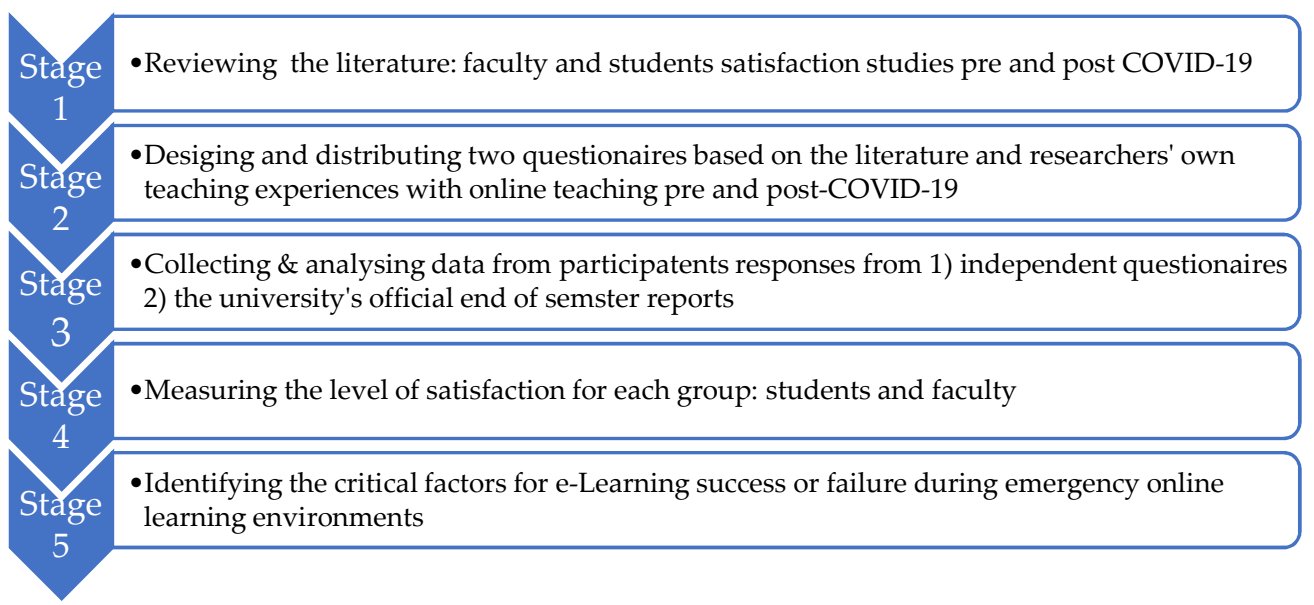

Figure 1. Research methodology framework.

In the first stage, literature studies related to the satisfaction of students and faculty, both prior to the pandemic and post-COVID-19, have been reviewed. In the following stage, with knowledge driven from the literature as well as from the researchers' own experiences as online instructors before and during the lockdown, the two questionnaires were designed and distributed to the intended groups. The questionnaires contained questions that were analysed in the third stage. Moreover, additional data were collected from KAU's end-of-semester reports. Next, in the fourth stage, using results obtained from the previous stage, the levels of satisfaction of both groups are measured. Finally, the most critical factors for E-Learning success and failure during emergency learning environments are identified.

\subsection{Data Collection}

The two questionnaires were created using Google Forms and distributed online via the LMS communication channels, KAU's proprietary mobile application known as $M y K A U$, mobile chat groups (WhatsApp), emails and text messages. Undergraduate students were randomly targeted through their instructors, and the same strategy was applied to faculty who were randomly targeted using their official university emails and shared fac- 
ulty mobile chat groups. All responses were anonymous and confidential; however, faculty were given the option to provide their emails for further communication. Eighty-three out of 213 faculty (almost 40\%) opted to provide their work emails. A clear question obtaining consent to participate in the study was provided at the beginning of each questionnaire, and the study objectives were clearly communicated, after which participants were asked to confirm that they were students or academic staff at the university. In addition, data were collected from official reports released by the university's Deanship of E-Learning and Distance Education.

Unlike the studies that were designed to measure the effectiveness and quality of an e-Learning system before the pandemic, this study describes a situation that was unique and difficult to predict. The questionnaires were developed during the term in which the lockdown was taking place, while the situation was unclear, change was happening on a daily basis and there were concerns that the researchers would not be able to reach students and staff once the summer break began. Most of the questions were in response to what was taking place during the emergency lockdown period, and the researchers started collecting the responses immediately. More time to reflect would have improved the robustness of the instruments and data collection phase.

\subsubsection{Instrument 1: Student Questionnaire}

This questionnaire had 45 questions in total and was presented to students in Arabic. It was divided into four main sections, the first of which asked about their demographic data such as their study level and GPA. The other three sections looked at different aspects of their online distance learning experience during the pandemic and addressed social and technical aspects, teaching and learning aspects and aspects concerning online assessment. This paper only presents the teaching and learning aspects, which had nine questions and three sub-questions to allow students to clarify or elaborate on their answers through a number of open-ended questions. In the teaching and learning section, seven questions used a 3-point scale (Agree, Neutral, Disagree), while another two questions asked about tools and methods of communication. Three questions gave the students the choice to explain their answers further via open ended questions and hence provide qualitative data insights.

\subsubsection{Instrument 2: Faculty Questionnaire}

This questionnaire was presented to the faculty in both Arabic and English (for nonArabic speaking international faculty members), had 47 questions in total and was divided into four main sections. The first section asked about demographic data such as teaching experience and academic ranking. The other three sections addressed different aspects of their online distance teaching experience, which included social and technical aspects, teaching and learning aspects and those aspects concerning online assessment. In the teaching and learning section analysed in this paper, there were 12 questions and one sub-question to allow faculty to clarify or elaborate on their answers regarding the best platform for virtual classes. Nine questions used a 5-point Likert scale (strongly agree, agree, neutral, disagree, strongly disagree), while another two questions asked about the learning platform. In addition, there was a final open-ended question for further suggestions to improve teaching and learning during lockdown.

\subsubsection{Instrument 3: King Abdulaziz University Resources}

According to a report published by the Deanship of E-Learning and Distance Education [35], the total number of LMS Blackboard users over the remaining seven weeks of the semester was $1,710,176$, starting from the first week of lockdown $(167,213)$ up to the seventh week $(223,007)$. As for Blackboard Ultra, which was used for conducting virtual classrooms, the total number of sessions created was 141,278 classes. These sessions lasted for approximately for $187,161 \mathrm{~h}$, with a total attendance of 2,048,317 students. Moreover, the total number of sessions (virtual classes delivered simultaneously across campus at a given time) was 33,154 . 
Furthermore, 60 online training sessions were delivered to students for which registration was voluntary and around 7594 students attended. Similarly, 55 training sessions were offered to faculty members and 8258 signed up to attend them. As for technical support provided by KAU, this included responses to 52,295 requests from faculty and students.

Additionally, students with special needs received attention [36]. Ten online training sessions were delivered using sign language, in addition to the design and production of videos that explained the university's e-Learning systems in sign language for reference.

Keeping in mind the large number and diverse backgrounds of students enrolled at the university, financial issues might have been a burden for some students as some did not have the means to connect. The university thus provided free laptops and delivered them to students in need during lockdown [36].

\section{Results}

\subsection{Participants: Students and Faculty}

A total of 547 students and 213 faculty responded to each of the corresponding questionnaire. The demographics of the of student and faculty participants, gathered through five questions in each questionnaire, are shown in Tables 1 and 2, respectively.

Table 1. Student demographics.

\begin{tabular}{lcc}
\hline \multicolumn{1}{c}{ Category } & Frequency & Percentage $\%$ \\
\hline Gender & 172 & \\
Male & 375 & $34.4 \%$ \\
Female & & $68.4 \%$ \\
Discipline & 188 & $34.4 \%$ \\
$\quad$ English Language Institute (Preparatory Year) & 155 & $28.3 \%$ \\
Faculty of Computing \& IT & 45 & $8.2 \%$ \\
Faculty of Engineering & 42 & $7.7 \%$ \\
Faculty of Science & 42 & $7.7 \%$ \\
Faculty of Medicine & 23 & $4.2 \%$ \\
Faculty of Economics \& Administration & 18 & $3.3 \%$ \\
Faculty of Arts \& Humanities & 34 & $6.2 \%$ \\
Other Faculties & & \\
Year & 188 & $34.4 \%$ \\
Preparatory Year (1st or 2nd semester) & 132 & $24.1 \%$ \\
Year 2 (3rd or 4th semester) & 79 & $14.4 \%$ \\
Year 3 (5th or 6th semester) & 79 & $14.5 \%$ \\
Year 4 (7th or 8th semester) & 61 & $11.2 \%$ \\
Year 5 (9th or 10th semester) & 8 & $1.5 \%$ \\
Year 6 (medicine only) & & \\
GPA & 184 & $33.6 \%$ \\
4.5 and above (A \& A+) & 244 & $44.6 \%$ \\
3.75-4.49 (B \& B+) & 94 & $17.2 \%$ \\
2.75-3.74 (C \& C+) & 25 & $4.6 \%$ \\
2.74 and lower (D \& D+) & & \\
\hline
\end{tabular}


Table 2. Faculty demographics.

\begin{tabular}{lcc}
\hline \multicolumn{1}{c}{ Category } & Frequency & Percentage $\%$ \\
\hline Gender & & \\
Male & 42 & $19.7 \%$ \\
Female & 171 & $80.3 \%$ \\
Discipline & & \\
English Language Institute & 74 & $34.7 \%$ \\
Faculty of Computing \& IT & 55 & $30.5 \%$ \\
Faculty of Science & 30 & $14.1 \%$ \\
Faculty of Dentistry & 10 & $4.7 \%$ \\
Faculty of Arts \& Humanities & 9 & $4.2 \%$ \\
Faculty of Economics \& Administration & 8 & $3.8 \%$ \\
Faculty of Medicine & 5 & $2.3 \%$ \\
Other Faculties & 22 & $5.7 \%$ \\
Ranking & & \\
Professor & 16 & $7.5 \%$ \\
Associate Professor & 25 & $11.7 \%$ \\
Assistant Professor & 72 & $33.8 \%$ \\
Lecturer Professor & 37 & $17.4 \%$ \\
Teaching Assistant & 10 & $4.75 \%$ \\
Language Instructor & 38 & $17.8 \%$ \\
IGIT & 7 & $3.3 \%$ \\
Other (Temp) & 8 & $3.75 \%$ \\
Teaching Experience & & \\
One year or less & 9 & $4.2 \%$ \\
2-5 years & 48 & $22.5 \%$ \\
6-10 years & 46 & $51.65 \%$ \\
10+ years & 110 &
\end{tabular}

\subsection{Data Analysis}

The quantitative data obtained from both online questionnaires were analysed by the frequency of student and faculty responses and were stated in percentages as well as descriptive analysis, as the subsequent sections will describe. Moreover, two statistical tests: the Mann-Whitney $U$ test and the chi-square test of independence have also been applied for further data analysis. On the other hand, any qualitative data resulting from open ended questions were analysed using the thematic analysis method.

\subsection{Findings from the Student Questionnaire}

\subsubsection{Quantitative Results}

Overall Perception Results

The questions presented in Table 3 were translated from Arabic, and all of them were positively worded questions. The table displays items that were in the students' questionnaire alongside their responses as well as the mean and standard deviation.

As can be seen in Table 3, in six out of seven questions about teaching and learning, students gave more positive than negative responses ( 6 out of 7 ). This indicates a more positive perception of their experience with online learning during the COVID-19 pandemic lockdown. This is further confirmed by the answers to the question about their overall experience with online distance learning, where only $11.9 \%$ found it to be negative (item 9).

The item that received a dominantly positive response is the one relating to students' ability to follow the instructor's explanation of the subjects online $(75.8 \%)$. This is followed by attendance $(75.5 \%)$. As the majority of participants in this study were females $(68.4 \%)$, online attendance could be more feasible for many of them due to transportation issues and family obligations. 
Table 3. Overall results of Instrument 1 (student perceptions of online learning).

\begin{tabular}{|c|c|c|c|c|c|c|}
\hline \multirow{2}{*}{ Items } & \multirow{2}{*}{ Category } & \multicolumn{3}{|c|}{ Responses } & \multirow{2}{*}{ Mean } & \multirow{2}{*}{$\begin{array}{l}\text { Standard } \\
\text { Deviation }\end{array}$} \\
\hline & & Agree & Neutral & Disagree & & \\
\hline 1 & $\begin{array}{l}\text { I was able to follow instructors' explanation } \\
\text { of the subjects online }\end{array}$ & $\begin{array}{c}409 \\
(74.8 \%)\end{array}$ & $0.00 \%$ & $\begin{array}{c}138 \\
(25.2 \%)\end{array}$ & 2.50 & 2.11 \\
\hline 2 & I participated in online classes & $\begin{array}{c}352 \\
(72.6 \%)\end{array}$ & $0.00 \%$ & $\begin{array}{c}150 \\
(27.4 \%)\end{array}$ & 2.20 & 1.96 \\
\hline 4 & I attended most of the online virtual classes & $\begin{array}{c}413 \\
(75.5 \%)\end{array}$ & $\begin{array}{c}116 \\
(21.2 \%)\end{array}$ & $\begin{array}{c}18 \\
(3.3 \%)\end{array}$ & 2.72 & 2.22 \\
\hline 5 & $\begin{array}{l}\text { I was able to interact and engage easily with } \\
\text { instructors during virtual classes }\end{array}$ & $\begin{array}{c}398 \\
(72.8 \%)\end{array}$ & $\begin{array}{c}128 \\
(23.4 \%)\end{array}$ & $\begin{array}{c}21 \\
(3.8 \%)\end{array}$ & 2.69 & 2.20 \\
\hline 6 & $\begin{array}{l}\text { I was able to interact and engage easily with } \\
\text { instructors after virtual classes }\end{array}$ & $\begin{array}{c}193 \\
(35.3 \%)\end{array}$ & $\begin{array}{c}255 \\
(46.6 \%)\end{array}$ & $\begin{array}{c}99 \\
(18.1 \%)\end{array}$ & 2.17 & 1.75 \\
\hline 8 & $\begin{array}{l}\text { The impact of virtual learning on my level of } \\
\text { comprehension was limited (if any) }\end{array}$ & $\begin{array}{c}95 \\
(17.4 \%)\end{array}$ & $\begin{array}{c}256 \\
(46.8 \%)\end{array}$ & $\begin{array}{c}196 \\
(35.8 \%)\end{array}$ & 1.82 & 1.40 \\
\hline 9 & $\begin{array}{l}\text { The overall experience of online distance } \\
\text { learning during lockdown was successful }\end{array}$ & $\begin{array}{c}257 \\
(47 \%)\end{array}$ & $\begin{array}{c}225 \\
(41.1 \%)\end{array}$ & $\begin{array}{c}65 \\
(11.9 \%)\end{array}$ & 2.35 & 1.91 \\
\hline
\end{tabular}

Many students (72.6\%) have reported a positive experience with participation in virtual classes. This could be an indication that remote learning, with the absence of cameras in our case, and having a chat tool (reported to be used by $82.6 \%$ of students in Table 3), helped shy or introverted students to participate without fear or anxiety.

Although more students found their interaction and engagement experience with their instructors after class to be positive, the overall percentage was only $35 \%$ compared to almost $73 \%$ during virtual classes. Having dedicated office hours online might not be ideal for after class communication compared with office hours on campus. In Table 3, 33.8\% of students reported using emails for after class communication, hence instructors might find it difficult to reply promptly to all email inquiries.

The only item that received more negative responses was item number 8: "The impact of virtual learning on my level of comprehension was limited". This could be due to a number of reasons, which were stated in open-ended questions (Section 4.3.2), such as the long lecture hours, technical issues, the nature of the subject, the of visibility as video was not used or not having a suitable environment for studying at home.

\section{The Relationship between Gender and Students' Perception}

As undergraduate studies in all Saudi universities take place on gender-segregated campuses, a research question regarding gender was investigated. The Mann-Whitney $\mathrm{U}$ test was conducted to understand whether students' perception about online learning, where perception is measured on an ordinal scale differ based on gender. The dependent variables were different questions determining the perception of students and used just the agree and disagree points in the 3-point scale. The results from the analysis as presented in Table 4 show that students' gender had no significant effect on their perceptions of online learning. This suggests that the distribution of the categories of student perceptions about online learning is the same across categories of gender.

Table 4. Test of significance of the effect of gender on student perceptions of online learning.

\begin{tabular}{|c|c|c|c|c|}
\hline $\mathbf{S} / \mathbf{N}$ & Perception Questions & Z Stat & Sig. & Remark \\
\hline Q1 & I was able to follow instructors' explanation of the subjects online & -0.34 & 0.734 & Not Significant \\
\hline$\widehat{\mathrm{Q}} 2$ & I participated in online classes & -0.08 & 0.935 & Not Significant \\
\hline$\widehat{Q} 4$ & I attended most of the online virtual classes & -0.21 & 0.834 & Not Significant \\
\hline Q5 & I was able to interact and engage easily with instructors during virtual classes & -0.23 & 0.815 & Not Significant \\
\hline Q6 & I was able to interact and engage easily with instructors after virtual classes & -0.04 & 0.969 & Not Significant \\
\hline Q8 & The impact of virtual learning on my level of comprehension was limited (if any) & -0.10 & 0.918 & Not Significant \\
\hline Q9 & The overall experience of online distance learning during lock-down was successful & -0.06 & 0.955 & Not Significant \\
\hline
\end{tabular}




\section{Preferred Tools for Participation and Communication}

The answers to two questions that asked students about their preferred tools for inclass participation and those used for contacting their instructors afterwards are presented in Table 5. The results illustrated that most students participated in class using the chat tool in Blackboard Ultra (82.6\%), followed by the voice tool (15\%). On the other hand, e-mail was the most popular method for after-class communication (33.8\%), followed by WhatsApp mobile chat group (28.3\%) and KAU's proprietary mobile application MyKAU $(21 \%)$. However, 62 students $(11 \%)$ stated that they never attempted to contact their instructors after class.

Table 5. Results of Instrument 1 (preferred tools for participation and communication).

\begin{tabular}{cccc}
\hline Questions & Responses & Frequency & Percentage $\%$ \\
\hline & Chat & 453 & $82.6 \%$ \\
Q3. The main tool you used for participation in & Voice & 81 & $14.8 \%$ \\
class was: & Video & 8 & $1.5 \%$ \\
& I did not participate & 5 & $1.1 \%$ \\
\hline & e-mail & 185 & $33.8 \%$ \\
Q7. The main method/tool you used for & WhatsApp Group & 115 & $28.3 \%$ \\
participation after class was: & MyKAU App & $11 \%$ & 62 \\
& Blackboard & 19 & $11.2 \%$ \\
\hline
\end{tabular}

The Relationship between Tools Used by Students and Their Socioeconomic Characteristics

\section{During Class:}

An additional sub-research question was explored: is there an association between the tool used by students and their socioeconomic characteristics?

A chi-square test of independence was conducted to determine the association between the tool used by the students for participation in class and their socioeconomic characteristics, as can be seen in Table 6 . The analysis was conducted with the aim of determining the factors that contribute to the choice of study instruments. The results indicated that the students' socioeconomic factors have no significant effect on their choice of study instrument during class.

- There was no statistically significant association between gender and type of study instrument used for participating class, $\chi 2(1)=0.02, p>0.05$.

- There was no statistically significant association between the student faculty and type of study instrument used for participating class, $\chi 2(4)=0.124, p>0.05$.

- There was no statistically significant association between year of study and type of study instrument used for participating class, $\chi 2(4)=0.019, p>0.05$.

- There was no statistically significant association between GPA and type of study instrument used for participating class, $\chi 2(3)=0.053, p>0.05$. 
Table 6. Factors associated with choice of study instrument (participation) during class.

\begin{tabular}{|c|c|c|c|c|}
\hline \multirow{2}{*}{ Sociodemographic Characteristics } & \multirow{2}{*}{ Category } & \multicolumn{3}{|c|}{ Main Tool for Participation in Class } \\
\hline & & Chat & Voice and Video & $p$-Value \\
\hline Gender & $\begin{array}{c}\text { Male } \\
\text { Female }\end{array}$ & $\begin{array}{c}142 \\
(31.2 \%) \\
313 \\
(68.8 \%)\end{array}$ & $\begin{array}{c}28 \\
(31.5 \%) \\
61 \\
(68.5 \%)\end{array}$ & $\begin{array}{c}0.963 \\
(0.002)\end{array}$ \\
\hline Year & $\begin{array}{c}\text { Prep } \\
\text { Year } 2 \\
\text { Year } 3 \\
\text { Year } 4 \\
\text { Year } 5 \text { and above }\end{array}$ & $\begin{array}{c}154 \\
(34 \%) \\
109 \\
(24.1 \%) \\
65 \\
(14.3 \%) \\
65 \\
(14.3 \%) \\
60 \\
(13.2 \%)\end{array}$ & $\begin{array}{c}30 \\
(33.7 \%) \\
21 \\
(23.6 \%) \\
13 \\
(14.6 \%) \\
13 \\
(14.6 \%) \\
12 \\
(13.5 \%)\end{array}$ & $\begin{array}{c}1 \\
(0.019)\end{array}$ \\
\hline Faculty & $\begin{array}{c}\text { Prep } \\
\text { CIE } \\
\text { (Comp/IT/Eng.) } \\
\text { SCM } \\
\text { (Science/Medicine) } \\
\text { EAAH } \\
\text { (Eco./Admin/Art/Hum) } \\
\text { Other }\end{array}$ & $\begin{array}{c}154 \\
(34 \%) \\
168 \\
(37.1 \%) \\
68 \\
(15 \%) \\
36 \\
(7.9 \%) \\
27 \\
(6 \%)\end{array}$ & $\begin{array}{c}30 \\
(30.2 \%) \\
33 \\
(33 \%) \\
13 \\
(14.6 \%) \\
8 \\
(9 \%) \\
5 \\
(5.6 \%)\end{array}$ & $\begin{array}{c}0.998 \\
(0.015)\end{array}$ \\
\hline GPA & $\begin{array}{l}\mathrm{A} \text { and } \mathrm{A}+ \\
\mathrm{B} \text { and } \mathrm{B}+ \\
\mathrm{C} \text { and } \mathrm{C}+ \\
\mathrm{D} \text { and } \mathrm{D}+\end{array}$ & $\begin{array}{c}154 \\
(34 \%) \\
204 \\
(45 \%) \\
77 \\
(17 \%) \\
18 \\
(4 \%)\end{array}$ & $\begin{array}{c}30 \\
(33.7 \%) \\
40 \\
(44.9 \%) \\
15 \\
(16.9 \%) \\
4 \\
(4.5 \%)\end{array}$ & $\begin{array}{c}0.997 \\
(0.010)\end{array}$ \\
\hline
\end{tabular}

\section{After Class:}

Another chi-square test of independence was conducted to determine the association between the method/tool used by the students for participation after class and their socioeconomic characteristics. The analysis was conducted with the aim of determining the factors that contribute to the choice of study instruments as seen in Table 7. The results indicated that the students' socioeconomic factors have no significant effect on their choice of study instrument after class.

- There was no statistically significant association between gender and method of instrument used for participating after class, $\chi 2(3)=0.02, p>0.05$.

- There was no statistically significant association between the student faculty and method of instrument used for participating after class, $\chi 2(12)=0.261, p>0.05$.

- There was no statistically significant association between year of study and method of instrument used for participating after class, $\chi 2(12)=0.155, p>0.05$.

- There was no statistically significant association between GPA and method of instrument used for participating after class, $\chi 2(9)=0.168, p>0.05$. 
Table 7. Factors associated with choice of Study instrument (communication) after class.

\begin{tabular}{|c|c|c|c|c|c|c|}
\hline \multirow{2}{*}{$\begin{array}{l}\text { Sociodemographic } \\
\text { Characteristics }\end{array}$} & \multirow{2}{*}{ Category } & \multicolumn{5}{|c|}{ Main Method for Participation after Class } \\
\hline & & Email & $\begin{array}{c}\text { Apps } \\
\text { (Whatsapp/MyKau) }\end{array}$ & BlackBoard/Others & No Contact & $p$-Value \\
\hline \multirow{2}{*}{ Gender } & Male & $\begin{array}{c}57 \\
(30.8 \%)\end{array}$ & $84(31.1 \%)$ & $\begin{array}{c}9 \\
(30 \%)\end{array}$ & $\begin{array}{c}19 \\
(30.6 \%)\end{array}$ & \multirow{2}{*}{$\begin{array}{c}0.999 \\
(0.006)\end{array}$} \\
\hline & Female & $\begin{array}{c}128 \\
(69.2 \%)\end{array}$ & $186(68.9 \%)$ & $\begin{array}{c}21 \\
(70 \%)\end{array}$ & $\begin{array}{c}43 \\
(69.4 \%)\end{array}$ & \\
\hline \multirow{6}{*}{ Year } & Prep & $\begin{array}{c}63 \\
(34.1 \%)\end{array}$ & $\begin{array}{c}92 \\
(34.1 \%)\end{array}$ & $\begin{array}{c}10 \\
(33.3 \%)\end{array}$ & $\begin{array}{c}21 \\
(33.9 \%)\end{array}$ & \multirow{6}{*}{$\begin{array}{l}1.000 \\
(0.010)\end{array}$} \\
\hline & Year 2 & $\begin{array}{c}44 \\
(23.8 \%)\end{array}$ & $\begin{array}{c}65 \\
(24.1 \%)\end{array}$ & $\begin{array}{c}8 \\
(26.7 \%)\end{array}$ & $\begin{array}{l}15 \\
(24.2 \%)\end{array}$ & \\
\hline & Year 3 & 27 & 39 & 4 & 9 & \\
\hline & Year 4 & 27 & $(14.4 \%)$ & $(13.4 \%)$ & $(14.5 \%)$ & \\
\hline & N- 50 & $\begin{array}{c}(14.6 \%) \\
24\end{array}$ & $\begin{array}{l}(14.4 \%) \\
35\end{array}$ & $(13.3 \%)$ & $(14.5 \%)$ & \\
\hline & Year $5 \&$ above & $(13 \%)$ & $(13 \%)$ & $(13.3 \%)$ & $(11.3 \%)$ & \\
\hline \multirow{5}{*}{ Faculty } & Prep & $\begin{array}{c}63 \\
(34.1 \%)\end{array}$ & $\begin{array}{c}92 \\
(34.1 \%)\end{array}$ & $\begin{array}{c}10 \\
(33.3 \%)\end{array}$ & $\begin{array}{c}21 \\
(33.9 \%)\end{array}$ & \multirow{5}{*}{$\begin{array}{c}1 \\
(0.013)\end{array}$} \\
\hline & $\begin{array}{c}\text { CIE } \\
\text { (Comp/IT/Eng.) }\end{array}$ & $\begin{array}{c}68 \\
(36.8 \%)\end{array}$ & $\begin{array}{l}100 \\
(37 \%)\end{array}$ & $\begin{array}{c}11 \\
(36.7 \%)\end{array}$ & $\begin{array}{c}23 \\
(37.1 \%)\end{array}$ & \\
\hline & $\begin{array}{c}\text { SCM } \\
\text { (Science/Medicine) }\end{array}$ & $\begin{array}{c}28 \\
(15.1 \%)\end{array}$ & $41(15.2 \%)$ & $\begin{array}{c}5 \\
(16.7 \%)\end{array}$ & $\begin{array}{c}9 \\
(14.5 \%)\end{array}$ & \\
\hline & $\begin{array}{c}\text { EAAH } \\
\text { (Eco./Admin/Art/Hum) }\end{array}$ & $\begin{array}{l}15 \\
(8.1 \%)\end{array}$ & $\begin{array}{c}22 \\
(8.1 \%)\end{array}$ & $\begin{array}{c}2 \\
(6.7 \%)\end{array}$ & $\begin{array}{l}5 \\
(8.1 \%)\end{array}$ & \\
\hline & Other & $\begin{array}{c}11 \\
(5.9 \%)\end{array}$ & $\begin{array}{c}15 \\
(5.6 \%)\end{array}$ & $\begin{array}{c}2 \\
(6.7 \%)\end{array}$ & $\begin{array}{c}4 \\
(6.5 \%)\end{array}$ & \\
\hline \multirow{4}{*}{ GPA } & A and $\mathrm{A}+$ & $\begin{array}{c}63 \\
(34.1 \%)\end{array}$ & $92(34.1 \%)$ & $\begin{array}{c}10 \\
(33.3 \%)\end{array}$ & $\begin{array}{c}21 \\
(33.9 \%)\end{array}$ & \multirow{4}{*}{$\begin{array}{c}1 \\
(0.010)\end{array}$} \\
\hline & $\mathrm{B}$ and $\mathrm{B}+$ & $\begin{array}{c}83 \\
(44.9 \%)\end{array}$ & $121(44.8 \%)$ & $\begin{array}{c}14 \\
(46.7 \%)\end{array}$ & $\begin{array}{c}28 \\
(45.2 \%)\end{array}$ & \\
\hline & $\mathrm{C}$ and $\mathrm{C}+$ & 32 & $\begin{array}{c}46 \\
(17 \%)\end{array}$ & 5 & 11 & \\
\hline & $\mathrm{D}$ and $\mathrm{D}+$ & $\begin{array}{c}7 \\
(3.8 \%)\end{array}$ & $\begin{array}{c}11 \\
(4.1 \%)\end{array}$ & $\begin{array}{c}1 \\
(3.3 \%)\end{array}$ & $\begin{array}{c}2 \\
(3.2 \%)\end{array}$ & \\
\hline
\end{tabular}

\subsubsection{Emerging Results from Open-Ended Questions}

One question (item 1, Table 3) asked students if it was easy to follow instructors' explanations of the subjects and keep up with them in virtual classes. Approximately 25\% gave negative responses; the reasons given to explain why were technical issues and poor internet connection. In addition, some mentioned the long sessions, since KAU retained the original timetable and duration of sessions as they were in physical face-to-face classes. Some students stated the lack of visibility or visual contact with the instructors and their peers as another reason. Other students referred to issues related to the nature of their course. One important aspect that was mentioned was related to mental health during the pandemic as some students were trying to cope and study while struggling with anxiety.

When asked why they did not participate in class (if they gave negative responses, as did $27.4 \%$ of students in Table 3, item 2), some responded that they simply did not want to participate, while others suggested that they either could not due to technical issues or did not know how to use the tools for participation. Moreover, when asked about the interaction and engagement in class (if they gave negative response, as did approximately $4 \%$ of students), the feedback given included students not asking questions in the first place, too many students asking at the same time, technical issues or the instructors not understanding students' question or feeling that they did not want to answer.

Using the thematic analysis method [37] for analysing qualitative data, six main themes emerged to summarize the answers to the challenges described earlier. As students answered in Arabic, all the quotes in this section have been translated into English.

1. Challenges:

- Technical Issues: Poor internet connection was the major issue faced by students during lockdown. It is an issue that is very frustrating to learners, as very little could be done to overcome it. This problem is doubled if there is an issue at both ends, making it almost impossible to attend the class. As one student commented: 'I faced 
IT problems from both ends; the voice was breaking from the instructor's side, while my own system kept signing me out'.

- Visibility: Many students stated that the lack of visibility or visual contact with the instructors and their peers resulted in lower levels of interaction and a general lack of motivation to attend or participate. One student noted: 'It was very annoying not seeing the normal academic surroundings and just relying on the instructor's voice. I would rather learn from YouTube videos, at least we could see the presenter!'

- Course Design and Delivery: Long online sessions or classes (exceeding two hours) might have put pressure on instructors, as some student reported feeling that the teachers were talking too fast as if they just wanted to finish the session. It also increased students' boredom and made them less excited to attend. These long sessions might have been bearable in physical lecture halls, but not during online classes. As noted by one student: 'Instructors were in such a hurry to finish, they explained things faster than normal'. Another student agreed: 'The instructor was reading and not explaining things the way we experienced in lecture halls'.

- Nature of the Subject and Practical Sessions: Not all subjects are equal when it comes to online learning; those studying subjects such as medicine and engineering found it difficult to adapt to virtual classes. A medical student said that it was 'very hard to study medicine online'; another added, 'Engineering subjects need to be taught in class'.

- Health and Mental Health-Related Issues: Students also mentioned feeling that some faculty were concerned about teaching, learning and assessment without realising that some students themselves tested positive for COVID-19, while others had family members with severe symptoms due to the virus and were struggling with this in addition to trying to learn online. One student stated: 'Faculty members did not seem to consider the possibility that one of the students had a confirmed case of Coronavirus in his/her family, which could cause him/her great psychological stress and tension in addition to the university pressure. If the student does not complain about his/her condition, this does not mean that his/her situation is fine, and his/her psychological state is good. Faculty members should be considerate of students'.

- Domestic Distractions: Many students explained that the problem they faced was related to their house environments not being ideal for online learning. Many were distracted by family members, especially female students who are also mothers to young children. The background noise at home prevented many students from being able to focus and follow up. One student noted: 'my family kept interrupting me'. Another student stated: 'the environment at home is not suitable [for online learning] so I could not concentrate'.

2. Benefits:

A number of students mentioned some additional key positive elements that were successfully implemented by the university.

- Lecture Recording: Unlike the traditional lectures in classrooms and lecture halls, in this emergency learning environment, the university's policy required all instructors to record their sessions and the LMS tools allowed it. This means that students could never miss a lecture and could see/listen to the recordings of what they missed if they did not fully understand. One student stated: 'The advantage of the remote lectures was the availability of recordings of lectures'.

- Availability of Learning Content During Class: In contrast with physical lectures, nothing gets wiped or obstructed by the instructor or fellow students. As one student put it: 'As for me, I understood more from a distance learning, because I can now see the screen clearly, when we were studying at the university, the whiteboard was covered most of the time and then wiped immediately, and this is what annoyed me the most'. 


\subsection{Findings from the Faculty Questionnaire}

\subsubsection{Quantitative Results}

Overall Perception Results

Table 8 displays questions that were in the students' questionnaire alongside their responses as well as the mean and standard deviation. Three of these questions (Q3, Q4 and Q11) were positively worded questions in which agreement is considered a good answer. On the other hand, questions 5-10 were negatively worded questions in which disagreement is considered a good answer.

Table 8. Overall results of Instrument 2 (faculty perceptions of online teaching).

\begin{tabular}{|c|c|c|c|c|c|c|c|c|}
\hline \multirow[b]{2}{*}{ Question } & \multirow[b]{2}{*}{ Category } & \multicolumn{5}{|c|}{ Responses } & \multirow[b]{2}{*}{ Mean } & \multirow[b]{2}{*}{$\begin{array}{l}\text { Standard } \\
\text { Deviation }\end{array}$} \\
\hline & & $\begin{array}{c}\text { Strongly } \\
\text { Agree }\end{array}$ & Agree & Neutral & Disagree & $\begin{array}{l}\text { Strongly } \\
\text { Disagree }\end{array}$ & & \\
\hline Q3 & $\begin{array}{c}\text { I found teaching via virtual classes } \\
\text { similar to teaching traditional } \\
\text { classes }\end{array}$ & $\begin{array}{c}15 \\
(7 \%)\end{array}$ & $\begin{array}{c}65 \\
(30.5 \%)\end{array}$ & $\begin{array}{c}35 \\
(16.4 \%)\end{array}$ & $84(39.4 \%)$ & $\begin{array}{c}14 \\
(6.6 \%)\end{array}$ & 2.92 & 2.62 \\
\hline Q4 & $\begin{array}{l}\text { I found teaching via virtual classes } \\
\text { easier than in traditional classes } \\
\text { I found student }\end{array}$ & $\begin{array}{c}14 \\
(6.6 \%)\end{array}$ & $\begin{array}{c}55 \\
(25.8 \%)\end{array}$ & $\begin{array}{c}41 \\
(19.2 \%)\end{array}$ & $84(39.4 \%)$ & $\begin{array}{c}19 \\
(8.9 \%)\end{array}$ & 2.82 & 2.52 \\
\hline Q5 & $\begin{array}{l}\text { interaction to be less than usual in } \\
\text { virtual classes compared to } \\
\text { traditional classes }\end{array}$ & $\begin{array}{c}87 \\
(40.8 \%)\end{array}$ & $\begin{array}{c}81 \\
(38 \%)\end{array}$ & $\begin{array}{c}11 \\
(5.2 \%)\end{array}$ & $31(14.6 \%)$ & $\begin{array}{c}3 \\
(1.4 \%)\end{array}$ & 4.02 & 3.65 \\
\hline Q6 & $\begin{array}{l}\text { I found student attendance to be } \\
\text { less than usual in virtual classes } \\
\text { compared to traditional classes }\end{array}$ & $\begin{array}{c}57 \\
(26.8 \%)\end{array}$ & $\begin{array}{c}69 \\
(32.4 \%)\end{array}$ & $\begin{array}{c}20 \\
(9.4 \%)\end{array}$ & $59(27.7 \%)$ & $\begin{array}{c}8 \\
(3.8 \%)\end{array}$ & 3.51 & 3.21 \\
\hline Q7 & $\begin{array}{l}\text { Quality of course assignments or } \\
\text { requirements were less than in } \\
\text { traditional classes }\end{array}$ & $\begin{array}{c}35 \\
(16.4 \%)\end{array}$ & $\begin{array}{c}47 \\
(22.1 \%)\end{array}$ & $\begin{array}{c}37 \\
(17.3 \%)\end{array}$ & $73(34.3 \%)$ & $\begin{array}{c}21 \\
(9.9 \%)\end{array}$ & 3.00 & 2.77 \\
\hline Q8 & $\begin{array}{l}\text { The inability of students to see their } \\
\text { instructor and vice versa affected } \\
\text { the learning } \\
\text { process negatively }\end{array}$ & $\begin{array}{c}28 \\
(13.1 \%)\end{array}$ & $\begin{array}{c}76 \\
(35.7 \%)\end{array}$ & $\begin{array}{c}55 \\
(25.8 \%)\end{array}$ & $47(22.1 \%)$ & $\begin{array}{c}7 \\
(3.3 \%)\end{array}$ & 3.33 & 2.98 \\
\hline Q9 & $\begin{array}{l}\text { I found difficulty adapting the } \\
\text { teaching materials to suit teaching } \\
\text { online via virtual classes }\end{array}$ & $\begin{array}{c}15 \\
(7 \%)\end{array}$ & $\begin{array}{c}36 \\
(16.9 \%)\end{array}$ & $\begin{array}{c}35 \\
(16.4 \%)\end{array}$ & $94(44.1 \%)$ & $33(15.5 \%)$ & 2.56 & 2.30 \\
\hline Q10 & $\begin{array}{l}\text { I felt there was not a lot of flexibility } \\
\text { in scheduling virtual classes' timing } \\
\text { The various tools and features }\end{array}$ & $\begin{array}{c}14 \\
(6.6 \%)\end{array}$ & $\begin{array}{c}39 \\
(18.3 \%)\end{array}$ & $\begin{array}{c}30 \\
(14.1 \%)\end{array}$ & $\begin{array}{c}98 \\
(46 \%)\end{array}$ & $\begin{array}{c}32 \\
(15 \%)\end{array}$ & 2.55 & 2.30 \\
\hline Q11 & $\begin{array}{c}\text { provided by the virtual platform, } \\
\text { such as screen sharing, voice and } \\
\text { whiteboard } \\
\text { supported my teaching online }\end{array}$ & $\begin{array}{c}86 \\
(40.4 \%)\end{array}$ & $\begin{array}{c}112 \\
(52.6 \%)\end{array}$ & $\begin{array}{c}9 \\
(4.2 \%)\end{array}$ & $\begin{array}{c}2 \\
(0.9 \%)\end{array}$ & $\begin{array}{c}4 \\
(1.9 \%)\end{array}$ & 4.28 & 3.82 \\
\hline
\end{tabular}

As illustrated in Table 4 below, five out of nine questions about teaching and learning received negative responses (Q3-Q6 and Q8) in addition to four positive responses by faculty. This indicates a mixed perception, which leans slightly negative, of their experiences with online learning, depending on the specific aspect that was being evaluated. The faculty gave more positive feedback on adapting teaching material to suit online learning, the flexibility of schedules, the tools used, the LMS adopted by KAU and the quality of students' work. On the other hand, they gave more negative responses when it came to online teaching being similar or easier than traditional teaching, interaction with students, student attendance and the lack of visibility. It is worth mentioning that responses to each item in the questionnaire did not show a large contrast among faculty member opinions.

\section{The Relationship between Gender and Faculty Perception}

The Mann-Whitney U test was used again to understand whether the faculty's perception about teaching online, where perception is measured on an ordinal scale, differ based on gender. The dependent variables were different questions determining the perception of faculty used just the agree and disagree points in the 5-point Likert scale. The results from the analysis as shown in Table 9 show that the faculty member's gender had no significant effect on their perceptions of online teaching. This suggests that the distribution of the categories of the faculty's perceptions about online teaching is the same across categories of gender. 
Table 9. Test of significance of the effect of gender on faculty perceptions of online teaching.

\begin{tabular}{|c|c|c|c|c|}
\hline $\mathrm{S} / \mathbf{N}$ & Perception Questions & Z Stat & Sig. & Remark \\
\hline Q3 & I found teaching via virtual classes similar to teaching traditional classes & -0.067 & 0.946 & Not Significant \\
\hline$\widehat{\mathrm{Q}} 4$ & I found teaching via virtual classes easier than in traditional classes & -0.016 & 0.987 & Not Significant \\
\hline Q5 & $\begin{array}{l}\text { I found student interaction to be less than usual in virtual classes compared to } \\
\text { traditional classes }\end{array}$ & -0.046 & 0.963 & Not Significant \\
\hline Q6 & $\begin{array}{l}\text { I found student attendance to be less than usual in virtual classes compared to } \\
\text { traditional classes }\end{array}$ & -0.073 & 0.942 & Not Significant \\
\hline Q7 & $\begin{array}{l}\text { Quality of course assignments or } \\
\text { requirements were less than in traditional classes }\end{array}$ & -0.116 & 0.908 & Not Significant \\
\hline Q8 & $\begin{array}{c}\text { The inability of students to see their instructor and vice versa affected the } \\
\text { learning process negatively }\end{array}$ & -0.026 & 0.979 & Not Significant \\
\hline Q9 & $\begin{array}{c}\text { I found difficulty adapting the teaching materials to suit teaching online via } \\
\text { virtual classes }\end{array}$ & -0.012 & 0.991 & Not Significant \\
\hline Q10 & $\begin{array}{l}\text { I felt there was not a lot of flexibility in scheduling virtual classes' timing } \\
\text { The various tools and features }\end{array}$ & -0.115 & 0.908 & Not Significant \\
\hline Q11 & $\begin{array}{l}\text { provided by the virtual platform, such as screen sharing, voice and whiteboard } \\
\text { supported my teaching online }\end{array}$ & -0.212 & 0.832 & Not Significant \\
\hline
\end{tabular}

\section{Preferred Tools for Online Teaching}

When asked about the best platform for virtual classes, $72.8 \%$ of instructors favoured Blackboard Ultra. The reasons given were that it was easy to use and access, efficient, scalable, flexible and had many tools and features such as automatically monitoring attendance and the ability to record video (required by university regulations). In addition, faculty reported that it had fewer technical issues even compared to traditional Blackboard and its virtual classrooms. Others added voice quality, and the fact that it is supported and approved by KAU, thus providing them with a sense of security and trust compared to unendorsed tools such as Zoom; Table 10 presents these results.

Table 10. Results of Instrument 2 (preferred tools for teaching virtual classes).

\begin{tabular}{|c|c|c|c|}
\hline Questions & Responses & Frequency & Percentage $\%$ \\
\hline \multirow{5}{*}{ Q1. The most used platform for virtual classes } & Blackboard & 75 & $35.2 \%$ \\
\hline & Blackboard Ultra & 187 & $87.8 \%$ \\
\hline & Zoom & 46 & $21.6 \%$ \\
\hline & Google Meet & 7 & $3.3 \%$ \\
\hline & Microsoft Teams & 4 & $1.9 \%$ \\
\hline \multirow{5}{*}{$\begin{array}{c}\text { Q2. The best platform for delivery } \\
\text { virtual classes }\end{array}$} & Blackboard & 18 & $8.5 \%$ \\
\hline & Blackboard Ultra & 155 & $72.8 \%$ \\
\hline & Zoom & 27 & $12.7 \%$ \\
\hline & Google Meet & 4 & $1.9 \%$ \\
\hline & Microsoft Teams & 4 & $1.9 \%$ \\
\hline
\end{tabular}

The Relationship between the Platform Used by Faculty and Their Socioeconomic Characteristics

An additional sub-research question was explored here: is there a relationship between the platform faculty uses most for virtual classes their socioeconomic characteristics? A chi-square test of independence was conducted to determine the association between the platform faculty uses most for virtual classes their socioeconomic characteristics. The analysis was conducted with the aim of determining the factors that contribute to the choice of online teaching platform used by the faculty as shown Table 11. The result indicated that the faculty' socioeconomic factors have no significant effect on their choice of teaching platform used for virtual classes.

- $\quad$ There was no statistically significant association between gender and platform used for virtual teaching, $\chi 2(1)=0.009, p>0.05$. 
- There was no statistically significant association between the faculty ranking and platform used for virtual teaching, $\chi 2(4)=0.012, p>0.05$.

- There was no statistically significant association between faculty department and platform used for virtual teaching, $\chi 2(4)=0.117, p>0.05$.

- There was no statistically significant association between teaching experience and platform used for virtual teaching, $\chi 2(2)=0.015, p>0.05$.

Table 11. Factors associated with choice of teaching instrument.

\begin{tabular}{|c|c|c|c|c|}
\hline \multirow{2}{*}{$\begin{array}{l}\text { Sociodemographic } \\
\text { Characteristics }\end{array}$} & \multirow[b]{2}{*}{ Category } & \multicolumn{3}{|c|}{ Main Tool for Teaching in Class } \\
\hline & & $\begin{array}{l}\text { Blackboard/Blackboard } \\
\text { Ultra }\end{array}$ & $\begin{array}{l}\text { Video Conferencing Tools } \\
\text { Such as Zoom }\end{array}$ & $p$-Value \\
\hline \multirow[b]{2}{*}{ Gender } & Male & $\begin{array}{c}52 \\
(19.8 \%)\end{array}$ & $\begin{array}{c}11 \\
(193 \%)\end{array}$ & \multirow{2}{*}{$\begin{array}{c}0.925 \\
(0.005)\end{array}$} \\
\hline & Female & $\begin{array}{c}210 \\
(80.2 \%)\end{array}$ & $\begin{array}{c}46 \\
(80.7 \%)\end{array}$ & \\
\hline \multirow{5}{*}{ Ranking } & Professor/Associate Prof & $\begin{array}{c}50 \\
(19.1 \%)\end{array}$ & $\begin{array}{c}11 \\
(19.3 \%)\end{array}$ & \multirow{5}{*}{$\begin{array}{c}1 \\
(0.006)\end{array}$} \\
\hline & Assistant Professor & $\begin{array}{c}89 \\
(34 \%)\end{array}$ & $\begin{array}{c}19 \\
(33.3 \%)\end{array}$ & \\
\hline & Lecturer Professor & $\begin{array}{c}45 \\
(17.2 \%)\end{array}$ & $\begin{array}{c}10 \\
(17.5 \%)\end{array}$ & \\
\hline & TA/Language Inst. & $\begin{array}{c}60 \\
(22.9 \%)\end{array}$ & $\begin{array}{c}13 \\
(22.8 \%)\end{array}$ & \\
\hline & Others & $\begin{array}{c}18 \\
(6.9 \%)\end{array}$ & $\begin{array}{c}4 \\
(7 \%)\end{array}$ & \\
\hline \multirow{7}{*}{ Faculty } & English Language & $\begin{array}{c}92 \\
(35.1 \%)\end{array}$ & $\begin{array}{c}20 \\
(35.1 \%)\end{array}$ & \multirow{7}{*}{$\begin{array}{l}0.998 \\
(0.019)\end{array}$} \\
\hline & $\begin{array}{c}\text { CI } \\
(\text { Comp/IT })\end{array}$ & $\begin{array}{c}68 \\
(26 \%)\end{array}$ & $\begin{array}{c}15 \\
(26.3 \%)\end{array}$ & \\
\hline & SDM & 55 & 11 & \\
\hline & (Science/Dentistry/Medicine) & $(21 \%)$ & $(19.3 \%)$ & \\
\hline & EAAH & 21 & 5 & \\
\hline & (Eco./Admin/Art/Hum) & $(8 \%)$ & $(8.8 \%)$ & \\
\hline & Other & $\begin{array}{c}26 \\
(9.9 \%) \\
\end{array}$ & $\begin{array}{c}6 \\
(10.5 \%)\end{array}$ & \\
\hline \multirow{3}{*}{ Teaching Experience } & 0 to 5 years & $\begin{array}{c}71 \\
(27.1 \%)\end{array}$ & $\begin{array}{c}15 \\
(26.3 \%)\end{array}$ & \multirow{3}{*}{$\begin{array}{c}0.992 \\
(0.007)\end{array}$} \\
\hline & 6 to 10 years & $\begin{array}{c}55 \\
(21 \%)\end{array}$ & $\begin{array}{c}12 \\
(21.1 \%)\end{array}$ & \\
\hline & $10+$ years & 136 & 30 & \\
\hline
\end{tabular}

\subsubsection{Emerging Results from Open-Ended Questions}

Faculty were presented with an optional open-ended question that asked for suggestions or comments to improve online teaching and learning. Eighty-three out of 213 academic staff $(40 \%)$ that answered the questionnaire responded to this particular question. Responses gathered were written either in Arabic or English. Using the thematic analysis method for analysing qualitative data, five main challenges emerged. Moreover, some of the key success factors that the students described were also mentioned.

1. Challenges:

- Course Design and Delivery: The majority of faculty agreed, similar to their students, that the length of online sessions needed to be reduced. Long hours of online teaching are tiring for the instructors and boring for the students, as suggested by the following 
quote: '[I suggest] changing the 3-4 $\mathrm{h}$ face-to-face hours in traditional teaching to $1-2 \mathrm{~h}$ online and the rest could be utilized offline because students can do other activities at their own pace'.

- Visibility: There were several suggestions to activate the webcam option in the virtual classroom to reduce both sides' sense of isolation, to increase motivation and to prevent students from the habit of logging in at the beginning of the session but not being actually there for the rest of it, as noted by a faculty member: 'Students can $\log$ in to give an impression that they are online but can physically be away, which cannot be thoroughly monitored. There should be some option which can monitor the student's continuous presence'.

- Training: Despite KAU's efforts on training during the pandemic lockdown, some faculty members still felt that more training is required for them to fulfil their duties. One stated: 'Mandatory professional development should be arranged for teachers before the next online teaching experience. The PD [Professional Development] should focus on how to engage learners, make instruction more interactive, and effectively manage troubleshooting'.

- Nature of the Subjects and Practical Sessions: Those who were teaching practical subjects, such as language skills, computer programming or science experiments, struggled to adapt their course content to distance learning at such short notice. The following quote reflects this: 'The teaching process is not suitable for laboratories and experiments. Can programs be developed that help students to represent experiments from a distance?'

- Technical Issues: Instructors felt that they had little control over the quality of the connection from their side and zero control over the connection from their students' sides. This might be a difficult obstacle to tackle or eliminate completely, but at least it should be considered while planning future sessions. In addition, there were other technical issues such as LMS's occasional technical glitches. One respondent stated: 'solutions are needed to eliminate glitching'.

2. Benefits:

An additional key positive success element was mentioned by faculty members. They noticed that online learning removed barriers for shy or introvert students, who normally did not participate or speak up in physical classes but had an opportunity to do so in virtual learning environments. As put by one faculty member: 'I think shy students participated more in distance learning'.

\section{Discussion}

The first stated question for this study asked: To what extent was a Saudi higher education institution, namely KAU, ready for an emergency lockdown? The results from the data collected using multiple resources showed that the university was ready to move to online learning and teaching to an acceptable extent. These results were measured according to the five pillars of the online learning quality framework [15,34]. These include the access pillar, the scale pillar and the learning effectiveness pillar, in addition to both the student and faculty satisfaction pillars.

Adequate hardware and software infrastructure were already in place, and both students and faculty had enough technical skills required for the shift. This included the servers, LMS, digital library and e-books. Online distance learning started from the first day of lockdown, and as soon as the university shifted to online learning, the university increased its support to its faculty and students through training sessions, technical support, support for students with special needs and financial support for underprivileged students in the form of laptops delivered to them at home. This satisfies the requirements of the access pillar, which includes three areas of support: 'academic (such as tutoring, advising, and library); administrative (such as financial aid, and disability support); and technical (such as hardware reliability and uptime, and help desk)' (OLC 2020). 
Moreover, all university students were able to continue learning online simultaneously, achieving the scale pillar, which 'enables institutions to offer their best educational value and to achieve capacity enrolment'.

Regarding the learning effectiveness pillar, which is concerned with 'ensuring that online students are provided with a high-quality education, online learning should at least be equivalent to that of traditional students' [34], the results of the questionnaires varied as the university strived to provide students who had to shift to online learning with an experience and resources equivalent to that which they had prior to lockdown. It provided the tools and means and kept the timetable and length of lectures. However, the results suggested that the latter might not have been ideal.

In terms of student satisfaction with the online distance learning experience, the majority of students gave positive answers. Moreover, when asked about their overall evaluation of the emergency distance learning experience, overall, $47 \%$ of students had a positive perception despite facing some difficulties, while $41 \%$ thought it was an experience that had positives and negatives and approximately $12 \%$ only found that it was a negative experience despite some positive outcomes. These responses indicate an acceptable level of satisfaction according to the student pillar of the framework.

As for faculty satisfaction, the majority gave slightly more negative responses. However, there was not a clear definite positive or negative perception towards e-Learning in the emergency lockdown period; responses depended on the aspect of teaching being evaluated. Faculty were, for example, satisfied with the infrastructure, technical support and training sessions, which aligns with the requirements of the faculty pillar. On the other hand, they reported problems with the length of the sessions, a lack of visibility that affected interactivity and not being able to ensure the full presence of students throughout the sessions. The difference in opinions regarding e-learning between students and faculty agrees with another study in the literature even prior the pandemic [38].

The results concerning the last two pillars are used to answer the second and third research questions regarding the factors for success and those that contributed to the challenges of online learning. The success factors were university readiness; these included a robust IT infrastructure, continuous training sessions, continuous IT support for technical problems and support for students from low-income families and those with special needs. Additionally, students liked the fact that all lectures were recorded and always accessible, which meant that no class was ever missed, even in the case of students' absence. Furthermore, students found the fact that nothing was wiped off the board or obstructed as a positive aspect of online learning. One success factor for the faculty was that online learning could remove barriers for shy or introverted students as it allowed them to participate and engage more during online sessions.

A number of challenges were shared between students and their instructors. These included technical issues such as poor internet connection, lack of visibility (cameras were not used by default for social reasons), course design (long sessions) and the nature of the study (practical sessions, for example for medicine and engineering courses). As for visibility, it is worth noting that despite some students complaining about the lack of visibility and faculty suggesting to allow video cameras to be turned on, there is no guarantee that students would actually proceed to do so, as was the case in a study in university in Bahrain [30]. In this study, students were given the option to attend and participate with or without video. Due to self-consciousness and lack of private space at home, many have opted not to use this option.

The students raised two additional concerns: distractions at home and issues related to anxiety and mental health. Faculty, on the other hand, wanted more training on making their classes more interactive as well as on handling technical difficulties.

All public and private learning institutions for undergraduate students in Saudi Arabia are physically segregated into separate campuses based on gender, and this continued to be the case in virtual learning. Therefore, the fourth question aimed to investigate the effect of gender on students and faculty perceptions towards online teaching and learning. The 
results showed that that neither the students' nor the faculty's gender had a significant effect on their perceptions of online learning.

The final research question asked was: What changes need to be made in order to capitalise on the success factors, address these challenges and improve the satisfaction of both students and faculty? A number of adjustments should be applied by policymakers and administrators in higher education, as will be further explained in the following section.

\section{Theoretical Implications on the Literature and Recommendations for Policy Makers}

This study adds value to previous literature concerning online distance learning in general and remote learning during emergency states in particular. It highlights key issues related to the success factors and challenges faced by users of online e-Learning systems in the context of a country in the Middle East such as Saudi Arabia during the COVID19 pandemic. The results confirm those of a recent study about how higher education institutes in GCC countries coped with the pandemic [33]. Unlike studies from other developing countries such as Pakistan [21,22], Indonesia [29] and Ghana [25,26], financial and monetary issues might not be the most concerning challenge to the majority of KAU students in Jeddah, the second largest city in Saudi Arabia. However, technical issues remain a shared factor affecting student and staff satisfaction, similar to results obtained from most empirical studies during lockdown, as mentioned in the literature review.

The findings from this study provide useful insights on what success factors might have led to student and faculty satisfaction, as well as barriers that need to be removed to increase satisfaction with E-Learning systems, especially during emergencies. The COVID19 pandemic still persists, and a second wave of the pandemic has been reported in many countries, forcing governments and local authorities to tighten their lockdown measures, and as such, the emergency online learning environments continue remotely. Even after the current pandemic is over, lessons learned from it could be applied to other emergencies such as extreme weather conditions, social or political unrest or new highly contagious pandemics emerging. Moreover, even without an emergency, some higher education institutions might encourage the use of online learning to achieve educational goals and financial gains, achieve better sustainability by reducing $\mathrm{CO}_{2}$ emissions or help students with challenges that might prevent them from attending classes on campus for short periods such as medical conditions or social and family obligations (for example students with small children or those who are mothers and breastfeeding). The below-mentioned factors should be taken into consideration when providing online learning:

- University Readiness:

This study confirmed what was pointed out by [20]. When reviewing how 20 universities worldwide dealt with the COVID-19 pandemic, they found that 'the responses by higher education providers have been diverse from having no response through to social isolation strategies on campus and rapid curriculum redevelopment for fully online offerings'. If the university was ready to integrate e-Learning into their teaching and learning systems before an emergency, then most likely, a higher level of user satisfaction will be achieved.

- Technical Issues:

No matter how innovative an e-learning system is or how high quality the teaching and content are, if students or academics cannot access the remote learning environment due to technical limitations such as limited internet access, then all participant experiences will be unsatisfactory. This is the most critical issue in online learning, as seen by most studies in the literature, and one that is not easy to tackle, as even in developed countries there are most likely some regions or areas of cities with poor internet access. The case could also be a matter of expenses; quality internet is available only if you pay higher rates. Another issue could be students lacking the equipment to connect, whether it be computers, tablets or smart phones; monetary aid from higher education institutions would be essential in this case. If the issue is 
related to expenses, it might be possible for universities to solve it by seeking financial aid from public or private bodies and allocating specific funds to help those students, as was the case with King Abdulaziz University. However, if the issue is related to the country's IT infrastructure or a student's geographical location, then alternative measures or solutions must be implemented to ensure that all students receive equal opportunities.

- Visibility and Social Aspects:

Students in this study want universities to allow and encourage the use of online video sessions to increase their motivation and facilitate interaction with their peers and instructors. The faculty also recommend the use of video in classes to ensure attendance and improve class interaction. However, as noted from the literature [30], this might not be the best choice or preferred option for all students due to personal or social reasons. Therefore, it is important to continue to rely on voice and other non-visible tools for communication while having video as an option that could be activated based on personal choices.

- Course Design:

Faculty and students recommend that the length of the sessions be adjusted for online format. Universities should thus aim to schedule shorter sessions, focusing on actual learning and not merely covering all aspects of the curriculum. Universities should also provide teachers and students with more interactive learning material suited for practical courses such engineering, languages and medicine.

- Training:

Universities should provide continuous technical and non-technical training for faculty and students alike, not only during emergency learning but also as a long-term plan for integrating e-Learning systems into their programs. This confirms the findings of other studies in the literature review $[38,39]$.

- Health:

Students want faculty to take into consideration issues related to their physical and mental health and wellbeing

- Students with Special Needs:

Students who have additional needs may face more challenges than their peers in e-Learning systems. They should not be left behind and should be taken into consideration in all aspects of course design, content creation and delivery, as well as training sessions [40].

\section{Conclusions}

COVID-19 presented an unprecedented challenge to modern societies at the beginning of 2020, and it continues to affect many aspects of people's lives including education. National and international lockdowns as well as social distancing rules aimed to contain the highly contagious virus prevented learning from being conducted as usual in classrooms and lecture halls. Online distance learning was a valid alternative that many universities across the globe have chosen to apply in order to survive the pandemic and stay in the game. Similar to any form of learning, it brought many opportunities to learners and presented them with challenges as well. As has been demonstrated in different empirical studies in the literature from different countries, many of its benefits are shared while the challenges could vary, depending on many factors such as each university's level of readiness prior the pandemic and other socioeconomic factors that might be specific to a certain country or region. This confirms the conclusions of [20], which after studying how universities from 20 courtiers have dealt with COVID-19 lockdown, it found that some universities were more prepared while others had more grounds to cover.

This paper presented a study of online distance learning experiences at King Abdulaziz University in Saudi Arabia during the first semester of the COVID-19 lockdown. This is a case study of a developing country in the Middle East that took into consideration the social aspects such as gender-segregation and the absence of video cameras. The main 
focus was to assess both student and faculty satisfaction in terms of teaching and learning, thus two self-administered questionnaires were used in addition to data collected from KAU's official reports. Results obtained from the questionnaires indicated a higher level of satisfaction among students compared to faculty, and also pointed out many challenges faced by students and faculty alike. The findings also showed that although virtual classes were strictly segregated by gender, neither faculty nor students' gender had any significant effect on their perceptions of online teaching and learning. Moreover, the results stated that faculty socioeconomic factors had no significant effect on their choice of teaching platform used for virtual classes. Similarly, students' socioeconomic factors had no significant effect on their choice of participation and communication preference with instructors during or after class.

The overall results showed that the university performed well in accordance with three of the five pillars of online learning quality framework [34], particularly in terms of student satisfaction, access and scalability. On the other, improvements are needed to achieve better results for faculty satisfaction and learning effectiveness. However, those findings should be viewed in the context of the challenging circumstances of the COVID-19 emergency lockdown. Nevertheless, some improvements and modifications in both technical and non-technical aspects are necessary in order to achieve a higher level of satisfaction for both students and faculty and to make online distance learning a viable option worthy of further investments in the near future.

Author Contributions: M.M.: contributed to instrument design, online distribution of the questionnaires, communication with university units, writing the literature review, analysing the data, writing the paper and putting it into the journal's format. Z.M.: contributed to instrument design and creation on Google Forms, translating teacher questionnaire into English, online distribution of the questionnaire and the reviewing, editing and proofreading of the paper. A.A.: Contributed to instrument design and creation on Google Forms, online distribution of the questionnaires and reviewing the paper. All authors have read and agreed to the published version of the manuscript.

Funding: This research received no external funding.

Institutional Review Board Statement: Not applicable.

Informed Consent Statement: Informed consent was obtained from all subjects involved in the study. A clear question obtaining consent to participate in the study was provided at the beginning of each questionnaire, and the study objectives were clearly communicated, after which participants were asked to confirm that they were students or academic staff at the university.

Data Availability Statement: Data available upon request from the corresponding author. Please note that most of original data are in Arabic.

Acknowledgments: Authors would like to thank all participants of the survey at King Abdulaziz University for their time, insights, comments and support.

Conflicts of Interest: The authors declare no conflict of interest.

\section{References}

1. Banas, E.J.; Emory, W.F. History Issues of Distance Learning. Public Adm. Q. 1998, 22, 365-383.

2. Darab, B.; Montazer, G.A. An eclectic model for assessing e-learning readiness in the Iranian universities. Comput. Educ. 2011, 56, 900-910. [CrossRef]

3. Fageeh, A.I. EFL students' readiness for e-learning: Factors influencing e-learners' acceptance of the Blackboard in a Saudi university. Jalt Call J. 2011, 1, 19-42. [CrossRef]

4. Salman, A.; Aziz, A.A. Evaluating user readiness towards digital society: A Rasch measurement model analysis. Procedia Comput. Sci. 2015, 65, 1154-1159. [CrossRef]

5. Whittle, C.; Tiwari, S.; Yan, S.; Williams, J. Emergency remote teaching environment: A conceptual framework for responsive online teaching in crises. Inform. Learn. Sci. 2020, 121, 311-319. [CrossRef]

6. Mtebe, J.S.; Raisamo, R. Investigating perceived barriers to the use of open educational resources in higher education in Tanzania. Int. Rev. Res. Open Distrib. Learn. 2014, 15, 43-66. [CrossRef]

7. Nwabufo, B.N.; TUmoru, A.; Olukotun, J.O. The Challenges of E-Learning in Tertiary Institutions in Nigeria. In Proceedings of the International Conference the Future of Education, Florence, Italy, 13-14 June 2013. 
8. Al Gamdi, M.; Samarji, A. Perceived barriers towards e-Learning by faculty members at a recently established university in Saudi Arabia. Int. J. Inf. Educ. Technol. 2016, 6, 23. [CrossRef]

9. Almaiah, M.A.; Alyoussef, I.Y. Analysis of the effect of course design, course content support, course assessment and instructor characteristics on the actual use of E-learning system. IEEE Access 2019, 7, 171907-171922. [CrossRef]

10. Vershitskaya, E.R.; Mikhaylova, A.V.; Gilmanshina, S.I.; Dorozhkin, E.M.; Epaneshnikov, V.V. Present-day management of universities in Russia: Prospects and challenges of e-learning. Educ. Inf. Technol. 2020, 25, 611-621. [CrossRef]

11. Aoki, K.; Pogroszewski, D. Virtual university reference model: A guide to delivering education and support services to the distance learner. Online J. Distance Learn. Adm. 1998, 1, 1-15.

12. Whittington, C.D.; Sclater, N. A Virtual University Model. In Proceedings of the World Conference of WWW, Internet and Intranet, Orlando, FL, USA, 7-12 November 1998.

13. Stein, H. A model of virtual university. Turk. Online J. Distance Educ. 2000, 1, 2.

14. Khan, B.H. The Global E-Learning Framework. 2003, p. 42. Available online: https://www.academia.edu/2478564/The_Global_ e-Learning_Framework_by_Badrul_H._Khan (accessed on 15 December 2020).

15. Moore, J.C. The Sloan Consortium quality framework and the five pillars. Sloan Consort. 2005, 15, 2007.

16. Bolliger, D.U.; Wasilik, O. Factors influencing faculty satisfaction with online teaching and learning in higher education. Distance Educ. 2009, 30, 103-116. [CrossRef]

17. Al-Gahtani, S.S. Empirical investigation of e-learning acceptance and assimilation: A structural equation model. Appl. Comput. Inform. 2016, 12, 27-50. [CrossRef]

18. Bellaaj, M.; Zekri, I.; Albugami, M. The continued use of e-learning system: An empirical investigation using UTAUT model at the University of Tabuk. J. Theor. Appl. Inf. Technol. 2015, 72, 464-474.

19. Algahtani, H.; Shirah, B.; Subahi, A.; Aldarmahi, A.; Ahmed, S.N.; Khan, A. Perception of Students about E-learning: A Single-center Experience from Saudi Arabia. Dr. Sulaiman Al Habib Med. J. 2020. [CrossRef]

20. Crawford, J.; Butler-Henderson, K.; Rudolph, J.; Malkawi, B.; Glowatz, M.; Burton, R.; Magni, P.A.; Lam, S. COVID-19: 20 Countries' Higher Education Intra-Period Digital Pedagogy Responses. J. Appl. Teach. Learn. 2020, 3, 1.

21. Abbasi, S.; Ayoob, T.; Malik, A.; Memon, S.I. Perceptions of students regarding E-learning during Covid-19 at a private medical college. Pak. J. Med. Sci. 2020, 36. [CrossRef]

22. Adnan, M.; Anwar, K. Online learning amid the COVID-19 pandemic: Students' perspectives. J. Pedagog. Sociol. Psychol. 2020, 2, 45-51. [CrossRef]

23. Almaiah, M.A.; Al-Khasawneh, A.; Althunibat, A. Exploring the critical challenges and factors influencing the E-learning system usage during COVID-19 pandemic. Educ. Inform. Technol. 2020, 25, 5261-5280. [CrossRef]

24. Tanveer, M.; Bhaumik, A.; Hassan, S. Covid-19 Pandemic, Outbreak Educational Sector And Students Online Learning in Saudi Arabia. J. Entrep. Educ. 2020, 23, 1-14.

25. Adarkwah, M.A. "I'm not against online teaching, but what about us?": ICT in Ghana post Covid-19. Educ. Inform. Technol. 2020, 6, 1665-1685. [CrossRef]

26. Agormedah, E.K.; Henaku, E.A.; Ayite, D.M.K.; Ansah, E.A. Online learning in higher education during COVID-19 pandemic: A case of Ghana. J. Educ. Technol. Online Learn. 2020, 3, 183-210.

27. Ionescu, C.; Paschia, L.; Nicolau, N.G.; Stanescu, S.; Stancescu, V.N.; Coman, M.; Uzlau, M. Sustainability Analysis of the E-Learning Education System during Pandemic Period-COVID-19 in Romania. Sustainability 2020, 12, 9030. [CrossRef]

28. Roslan, N.S.; Halim, A.S. Enablers and Barriers to Online Learning among Medical Students during COVID-19 Pandemic: An Explanatory Mixed-Method Study. Sustainability 2021, 13, 6086. [CrossRef]

29. Rohman, M.; Marji; Sudjimat, D.A.; Sugandi, R.M.; Nurhadi, D. Online learning in higher education during covid-19 pandemic: Students' perceptions. J. Talent Dev. Excell. 2020, 12, 3644-3651.

30. Al Mahadin, L.; Hallak, L. The Lack of Visual Interaction in Online Classes and its Effect on the Learning Experience of Students during the COVID-19 Pandemic: A Survey of a Bahraini Private University Students. 2021. Available online: https: / / papers.ssrn.com/sol3/papers.cfm?abstract_id=3874420 (accessed on 5 July 2021).

31. Weitze, C.L.; Ørngreen, R.; Levinsen, K. The global classroom video conferencing model and first evaluations. In Proceedings of the 12th European Conference on E-Learning: SKEMA Business School, Sophia Antipolis, France, 30-31 October 2013.

32. Raes, A.; Vanneste, P.; Pieters, M.; Windey, I.; Noortgate, W.V.D.; Depaepe, F. Learning and instruction in the hybrid virtual classroom: An investigation of students' engagement and the effect of quizzes. Comput. Educ. 2020, 143, 103682. [CrossRef]

33. Bensaid, B.; Brahimi, T. Coping with COVID-19: Higher education in the GCC countries. In Research and Innovation Forum 2020: Disruptive Technologies in Times of Change; Springer International Publishing: Cham, Switzerland, 2021.

34. OLC. Online Learning Consortium Quality Framework. 2020. Available online: https://onlinelearningconsortium.org/about/ quality-framework-five-pillars/ (accessed on 10 August 2020).

35. KAU_DDL. The Final Report for Activating Distance Education and Electronic Exams in the Second Semester of the Academic Year 1440-1441 AH (Translated from Arabic). Deanship of E-Learning and Distance Education. Unpublished work. 2020.

36. KAU_Web. The University Launches an Initiative to Provide Computer Devices to Students in Need Who Are unable to Access Electronic Systems; (Translated from Arabic). 2020. Available online: https:/ / www.kau.edu.sa/Content-0-AR-277815 (accessed on 11 August 2020).

37. Braun, V.; Clarke, V. Using thematic analysis in psychology. Qual. Res. Psychol. 2006, 3, 77-101. [CrossRef] 
38. Alhabeeb, A.; Rowley, J. E-learning critical success factors: Comparing perspectives from academic staff and students. Comput. Educ. 2018, 127, 1-12. [CrossRef]

39. Muhammad, G.; Albejaidi, F.; Akhtar, R. Challenges in development of eLearning systems in higher education of the developing countries. Lond. J. Res. Humanit. Soc. Sci. 2017, 1, 13-31.

40. Cooper, M.; Ferguson, R.; Wolff, A. What can analytics contribute to accessibility in e-learning systems and to disabled students' learning? In Proceedings of the Sixth International Conference on Learning Analytics \& Knowledge, Edinburgh, UK, 25-29 April 2016. 